\title{
めっきの柔軟性の測定と問題点（III）
}

Measurement of Ductility of Electrodeposits

and its Problems (III)

\author{
小 西 三 郎*，市 村 達 郎 $* *$ \\ Saburo KONISHI*, Tatsuro ICHIMURA**
}

いろいろの方法で測定したニッケルめっきの柔軟性は, めっき夜の組成やめっ き条件が同じであっても大きく異なる場合がある。この原因について追求した。

\section{6. 各種の試験法で得られた}

\section{ニッケルめっきの伸び}

\section{6-1 問題点}

以上の実験結果から代表的なニッケルめっきにつ いて, マイクロメータによる曲げ試験と引張試験 で得られた伸び\%をまとめてみると, 図15に示し たようになる。すなわち, 電着応力減少剤とレべ
ラーを併用した浴からの光沢ニッケルめっきの曲 げ試験と引張試験による伸び\%はよく一致してい る。

しかし, 引張試験で10数\%〜30数\%の伸びを示し たニッケルめっきは，マイクロメータによる曲げ 試験では $100 \%$ の伸びを示し，またマンドレルに よる曲げ試験での伸びは, 引張試験とマイクロメ ータによる曲げ試験の中間值を示した。

めっき厚さと伸びの関係については次のように

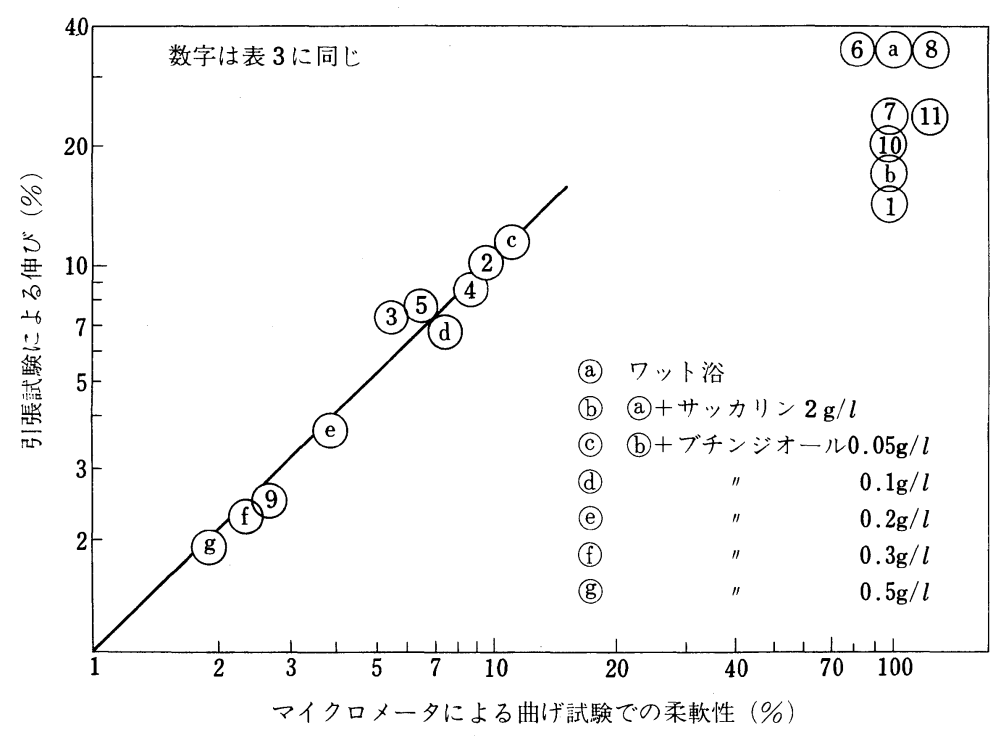

図15 各種ニッケルめっきのマイクロメータによる曲げ試験 での柔軟性\%と引張試験での伸び\%との関係 なった。マイクロメータに よる曲げ試験では, めっき 箔の厚さが厚くなると柔軟 性\%は低下した。しかしマ ンドレルによる曲げ試験で のめっきの伸びはめっき厚 さには，関係しなかった。 めっきをした引張試験片で 測定した伸びは,ワット浴 からのニッケルめっきでは めっき厚さに関係はなかっ たが, 光沢ニッケルめっき の伸びは, めっき厚さの増 加ととあに低下し，あるめ っき厚さで一定となった。

析出物のみから作成した

* 大阪府立工業技術研究所 主任研究員 个 577 東大阪市高井田中 1 - 38 $06-783-3051$

** 奥野製薬工業(株) 研究員

产 538 大阪市鶴見区放出東 $1-10$ $06-961-7781$
* Osaka Prefectural Industrial Research Institute 1-38, Takaidanaka, Higashi-osaka-shi, Osaka 577 **Okuno Chemical Industry Co., Ltd.

10, Hanaten Higashi 1-chome, Tsurumi-ku, Osaka 538 
引張試験片での引張試験による伸びは, 筆者らの 実験では再現性が悪く実験を中止したが, Brenner $ら^{2)}$ の実験結果では図16に示したようにワット浴 からのニッケルめっきの伸びはめっき厚さの増加 ととあに大きくなっている。乙のような傾向は水 本ら ${ }^{19)}$ や平松 ${ }^{20)}$ の実験結果に屯見られる。

以上のようにめっきの伸び\%は，測定法によっ て大きく異なる。たとえばワット浴から標準的な めっき条件で得られたニッケルめっきの伸びは, 数\%から $100 \%$ 以上な゙ある。また各種のめっき の伸びは Safranek ${ }^{15)}$ によってまとめられている が, 浴組成抢よびめっき条件に大差がないのに伸 び\%が大きく異なっている。

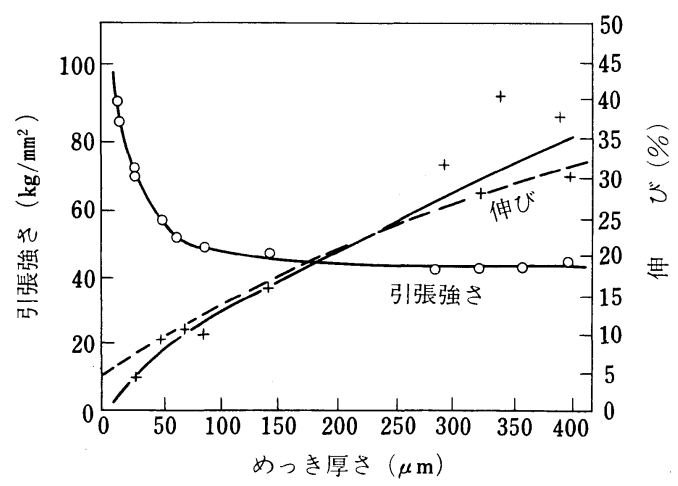

図16 ワット浴からのニッケルめっきのめっき厚さと 引張強さおよび伸びの関係( Brennet らによる)

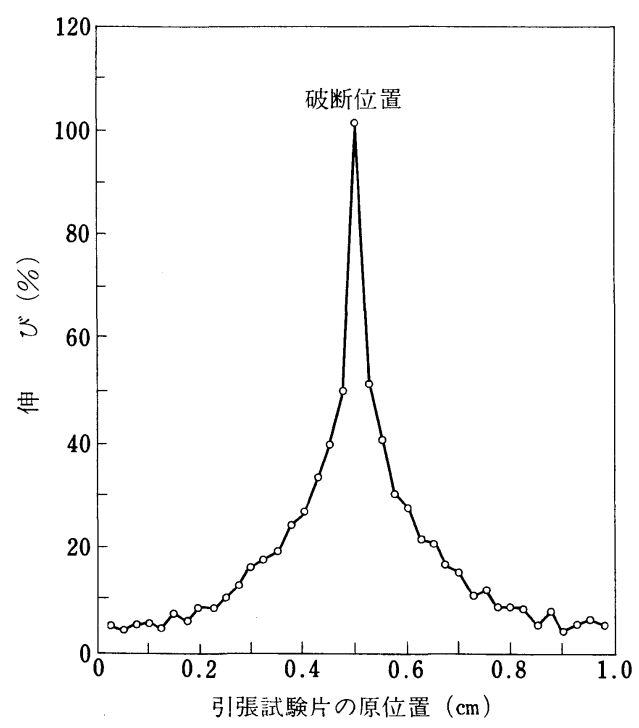

図17引張試験片の各位置での伸び\%(水本らによる)
めっきの引張試験と曲げ試験による伸びは, 試 験片への荷重のかかり方によって異なった結果に なるといわれている。 張試験ではなく曲げ試験で評価すべきであるとあ いわれている。 そこてでてれらについて詳しく検討 した。

\section{6-2 引張試験での伸び\%}

(1) 引張試験片の厚さと標点間距離

通常の引張試験での伸び\%は, 引張試験片の破 断前後の標点間距離の変化から(4)式を用い計算し ている。しかし，ての場合の標点間距離の伸びは 一様ではなく破断個所でのくびれ伸びが大きい。 図17は水本ら ${ }^{19)}$ が $0.25 \mathrm{~mm}$ 間隔に刻線を入れたSUS 304 上に硫酸銅めっき浴からめっきを行い, てれをはく離して作った引張試験片で標点間距離 $l_{0}=10 \mathrm{~mm}$ にて引張試験を行い, 求めた引張試 験片各部の伸び\%である。

切断部では $100 \%$ 以上の伸びを示し, 切断部よ り遠くなるに従い伸びは次第に小さくなっている。 このてとから, 引張試験で得られる伸び\%は標点 間距離の影響を受け, 標点間距離を短かくすると 大きく, 標点間距離を長くすれば小さくなること がわかる。

引張試験での全伸び $\mathrm{E}$ 引張試験片の標点間距 離 $l_{0}$ 之厚断面積 $\mathrm{A}_{0}$ をあらわす次の二つの式がある。 その一つはUnwin-Barbaの次式である。

$$
\mathrm{E}=\mathrm{a}+\mathrm{b} \sqrt{\mathrm{A}_{0} / l_{0}}
$$

$\mathrm{a}, \mathrm{b}$ は定数で, $\mathrm{a}$ は均一伸び， $\mathrm{b}$ を含む項は, くびれ伸びをあらわすといわれている。あう一つ は Oliver の式

$$
\mathrm{E}=\mu\left(\sqrt{\mathrm{A}_{0} / l_{0}}\right)^{\alpha}
$$

で， $\mu, \alpha$ は定数である。

この場合の $\mathrm{A}_{0}$ は引張試験片の平行部の幅と厚さ の積であるので, 引張試験片の幅が一定の場合に は, 全伸びは標点間距離の関数となる。

\section{これらの式を図16の Brenner ら 2)の実験結果}

（実線は Brenner らが, 又破線は筆者らが引いた 線である）に適用すると，Brenner ら ${ }^{2)}$ が使用し た引張試験片の幅は $12.5 \mathrm{~mm}$, 標点間距離は $50 \mathrm{~mm}$, であるので結果は図18に示したようになった。

Unwin-Barba の式では実線, 破線ともに直線 にはならないが, Oliver の式では実線は直線, 破 

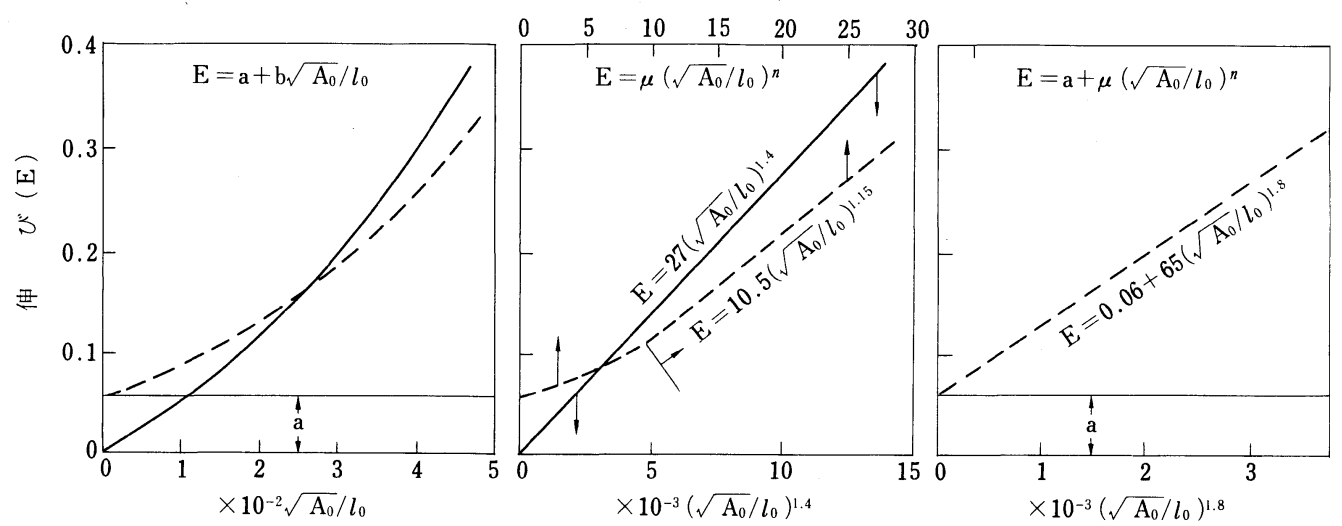

図18 引張試験における伸び $\mathrm{E}$ と引張試験片の厚断面積 $\mathrm{A}_{0}$ および標点間距離 $l_{0}$ の関係

線はめっき厚さが $0.05 \mathrm{~mm}$ 以上で直線となった。 また，Unwin-Barba と Oliver の式を組合せた式 では破線で直線関係が得られた。

このBrenner ら ${ }^{2)}$ の実験の伸びは，全伸びでは なく破断した引張試験片をつなぎ合せて測定した 永久伸びであるが， Oliver の式を満足している。 I SOの I S 2566/1では, ある引張試験片で得ら れた伸びを, 同じ材料であるが形状が異なった引 張試験片で得られた伸びに換算するのに Oliver の式が用いられている。乙れは J ISZ 2201-1980 の解説にもとりあげられているが, すべての材料 や試験片の形状について検討されていないととか ら J IS Z 2201-1980では，その採用が見送られ ている。

Brenner ら ${ }^{2)}$ は図16のめっき厚さと伸びおよび 引張強さの関係を光学顕微鏡で観察し, 析出物の グレンサイズの変化で説明している。グレンサイ ズが大きくなれば，降伏強さは低下するという Hall-Petch の式があるが, めっき厚さと伸びの関 係は, グレンサイズの変化だけではなく, 試験片 の厚断面積と標点距離に関係する材料力学的因子 が非常に大きいと考えられる。

(2) めっき箔の作製方法

Brenner ら² はステンレス鋼またはインコネル 板上（どちらかは不明）にめっきを行い,ニッケル めっき箔の引張試験片を作製し実験している。筆 者らは, ニッケルフラシュめっき後, 重クロム酸 ナトリウム溶液に浸せきして, 不働態化処理した 上にめっきを行い作製したニッケルめっき箔の引 張試験片で伸びを測定したが, その現再性はよく
なかった。最近の文献であめっき箔の引張試験で 伸びを測定する場合, 再現性のよい結果を得るた めにはめっき浴と素地の種類の関係は重要である といわれている。たとえば, 光沢ピロリン酸銅浴 ではSUS 304亿めっきして作製した引張試験片 では再現性がよい結果が得られたが, ${ }^{23)}$ 光沢硫酸 銅浴からSUS 304 にめっきして作製した引張試 験片では再現性の良好な結果が得られなかったと 報告されている。

しかし, 素地材料をインコネル600（ニッケル $72 \%$, 鉄 6 10\%, クロム14 17\%）に変えると 光沢硫酸銅浴でも再現性がよい結果が得られたと いわれている

したがって, 引張試験でめっきの伸び測定する ためのめっき箔の作製においては，素地金属の材 質も重要であるといえる。

(3) めっきした引張試験での伸び

めっきした引張試験片でのめっきの伸びの測定 では, めっき厚さに比べ素地の引張試験片が厚い ので, めっき厚さが多少変化しても引張試験片全 体の厚さには大きな変りはない。したがって前述 のめっき箔の場合のような標点間距離とめっき厚 さの影響は受けにくい。

事実, 筆者らが測定したワット浴からめっきし た引張試験片でのニッケルめっきの伸びは, めっ き厚さに関係なく $30 \%$ 以上であり，めっき厚さが うすい場合で屯めっきにクラックは認められなか った。乙のてとは, 前述のめっき箔の引張試験に おけるめっき厚さと伸びの関係のグレンサイズ説 を否定している。 


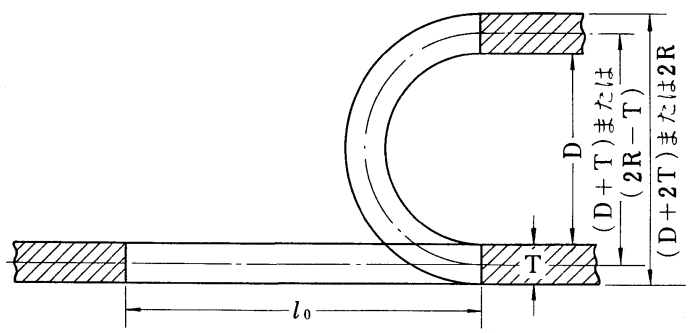

図19曲げ試験のモデル

しかし，光沢ニッケルめっきでは伸びが一定と なるめっき厚さがあり，また引張試験片の素材の 伸びは，めっきの伸びより屯大きくなければなら ないととは前述のとおりである。

\section{6-3 曲げ試験での伸び}

曲げ試験でのめっきの伸び\%は(1)または(3)式か ら求めたが，乙れは次のような伸び\%である。い ま図19に示した長さ $l_{0}$, 厚さ $\mathrm{T}$ の試験片を直径 $\mathrm{D}$ のマンドレルまたはマイクロメータで $2 \mathrm{R} （=\mathrm{D}$ +2 T ）に曲げた場合，破線で示した中心線は伸 び縮みせず $l_{0}$ で外側が伸び，内側 は収縮する。乙 の場合 $l_{0}$ 之試験片の最外層部の長さ $l$ は, それぞれ

$$
\begin{aligned}
& l_{0}=\pi(2 \mathrm{R}-\mathrm{T})=\pi(\mathrm{D}+\mathrm{T}) \cdots \cdots \\
& l=2 \pi \mathrm{R}=\pi(\mathrm{D}+2 \mathrm{~T}) \quad \cdots \cdots \cdots \cdots \cdots
\end{aligned}
$$

となる。乙れから $\left(l-l_{0}\right) / l_{0}$ を求めると(1)ま たは(3)式が得られる。

すなわち，曲げ試験では $\pi(2 \mathrm{R}-\mathrm{T})$ または $\pi(\mathrm{D}+\mathrm{T})$ が原標点間距離 $\mathrm{l}_{0}$ となる。乙の $\mathrm{l}_{0}$ は 引張試験のように最初から規定することはできな いので, 曲げ試験ではめっきにクラックが発生し た時点での $\pi(\mathrm{D}+\mathrm{T})$ ，またはめっきが破断し
たときの $\pi(2 \mathrm{R}-\mathrm{T})$ が原標点間距離となる。 たとえばワット浴，乙れに電着応力減少剤のみ を加えた浴およびワイスベルグ浴から得た厚さ 0.035 $\mathrm{mm}$ のニッケルめっき箔のマイクロメータによる 曲げ試験では，2 R=2 Tに折り曲げても破断せず $100 \%$ 以上の伸びを示した。乙の場合の原標点間 距離は $0.11 \mathrm{~mm}$ となる。乙のことは，いま 0.035 $\mathrm{mm}$ のニッケルめっき箔を原標点間距離 $0.11 \mathrm{~mm}$ で引張試験を行ったとすれば伸びは $100 \%$ 以上に なることを示唆している。

これに対して厚さ $1 \mathrm{~mm}$ の黄銅板上にワット浴, これに電着応力減少剂のみを加えた浴およびワイ スベルグ浴から 0.0125 0.025 mm のニッケルめ っきを行った試験片ではマンドレルなしで試験片 の内側が密着するように折り曲げた場合, 表 1 に 示すような結果が得られた。

この場合の曲げ試験片の最外層の伸びは，いず れあ $100 \%$ であり，マイクロメータによる曲げ試 験の伸び\%と同じであるにあかかわらず，めっき に発生したクラックに差が見られるのは原標点距 離が $3.2 \mathrm{~mm}$ であったからである。

電着応力減少剤とレベラーを併用した浴からの 柔軟性にとぼしい光沢ニッケルめっきでは引張試 験と曲げ試験の伸び\%がよく一致するのは，曲げ 試験でクラックが発生した $\pi(2 \mathrm{R}-\mathrm{T}) ， \pi(\mathrm{D}$ $+\mathrm{T})$ と引張試験における標点間距離と大差がな かったためである。

興味あるのはサッカリン $2 \mathrm{~g} / l+$ +ブチンジオー ル $0.05 \mathrm{~g} / l$ 浴からの光沢ニッケルめっきとワィ スベルグ浴からの光沢ニッケルーコバルト合金め

\begin{tabular}{|c|c|c|c|c|c|c|c|c|c|}
\hline \multirow{3}{*}{$\begin{array}{c}\text { マンドレル } \\
\text { の直径 D } \\
(\mathrm{mm})\end{array}$} & \multicolumn{2}{|c|}{$\begin{array}{l}\text { 伸 び (\%) } \\
\text { めっき厚さ }\end{array}$} & \multirow{3}{*}{ ワット浴 } & \multirow{3}{*}{$\begin{array}{l}\text { ワイスベ } \\
\text { ルグ浴 }\end{array}$} & \multirow{2}{*}{\multicolumn{5}{|c|}{$\begin{array}{l}\text { サッカリン } 2 \mathrm{~g} / l \\
\text { ブチンジオール }(\mathrm{g} / \mathrm{l})\end{array}$}} \\
\hline & \multicolumn{2}{|c|}{ めっき厚さ } & & & & & & & \\
\hline & $12.5 \mu \mathrm{m}$ & $25 \mu \mathrm{m}$ & & & 0 & 0.1 & 0.2 & 0.3 & 0.5 \\
\hline 0 & 100 & 100 & 0 & $x$ & $\triangle$ & $x$ & $\times$ & $\times$ & $x$ \\
\hline 2 & 33.6 & 33.9 & O & $\triangle$ & 0 & $\times$ & $\times$ & $\times$ & $\times$ \\
\hline 4 & 20.1 & 20.4 & O & 0 & O & $\times$ & $\times$ & $\times$ & $\times$ \\
\hline 6 & 14.4 & 14.6 & O & 0 & 0 & $\times$ & $\times$ & $\times$ & $\times$ \\
\hline 8 & 11.2 & 11.4 & O & O & 0 & $\triangle$ & $x$ & $x$ & $x$ \\
\hline 10 & 9.2 & 9.3 & 0 & 0 & 0 & $\bigcirc$ & $\triangle$ & $\times$ & $\times$ \\
\hline 25 & 3.9 & 3.9 & $\bigcirc$ & 0 & 0 & $\bigcirc$ & 0 & $\triangle$ & $x$ \\
\hline
\end{tabular}
る曲げ試験での結果 


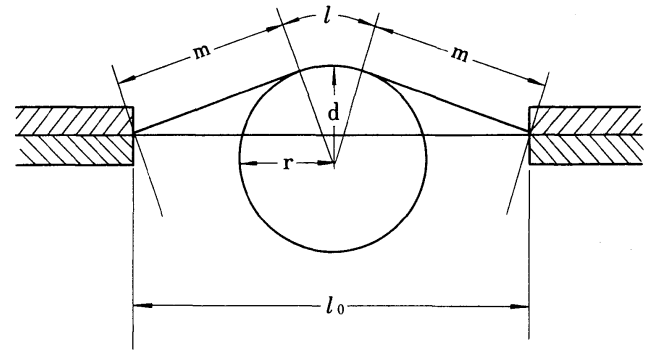

図20 Ductility Tester の模式図

っきである。これらのニッケルめっきの引張試験 での伸びは $11 \%$ と $13 \%$ と大差がなかった。

しかし, 前者はマイクロメータによる曲げ試験 と引張試験での伸びがほとんど同じであったにあ かかわらず, 後者はマイクロメータによる曲げ試 験では $100 \%$ の伸びを示した。この場合の曲げ試 験での標点間距離は大きく異なる。乙のような結 果はワイスベルグ浴からの光沢ニッケルーコバル 卜合金めっきのくびれ伸びが大いためであろう。

一般に電着応力減少剂にレベラーを併用した浴 からの光沢ニッケルめっきの柔軟性がよくないの は，くびれ伸びが小さいためであると考えられる。 また光沢ニッケルー鉄合金めっき箔がマイクロメ ータによる曲げ試験で $100 \%$ の柔軟性を示すのも くびれ伸びが大きいためであろう。

\section{6-4 Ductility Tester によるめっきの伸び}

沖中ら ${ }^{25)}$ にって考案された Ductility Tester によるめっきの柔軟性は，中村ら ${ }^{51}$ にってて測定 されており，ての Ductility Tester によるめっき の柔軟性試験法はASTMでの採用が検討されてい
るといわれている。

この Ductility Tester の概略は, 図20に示し たようにめっき䇴を直径 $l_{0}=7 \mathrm{~mm}$ のリングで 固定し, その中央を半径 $\mathrm{r}=1.59 \mathrm{~mm}$ の鋼球で押 し上げ, めっき箔が破壊するまでの鋼球の移動距 離 $\alpha$ からめっきの伸び $\mathrm{E} \%$ を次式

$$
\mathrm{E} \%=\frac{l-l_{0}}{l_{0}} \times 100
$$

から求める。乙の式は引張試験での伸び\%を求め る(4)式と同様であるが, この場合は

$$
\begin{aligned}
& l=2 \mathrm{~m}+l^{\prime} \\
& \mathrm{m}=\sqrt{\left(l_{0} / 2\right)^{2}+(\mathrm{r}-\mathrm{d})^{2}-\mathrm{r}^{2}} \cdots \cdots \\
& l^{\prime}=2 \mathrm{r} \tan ^{-1} \frac{\mathrm{r} l_{0}-2 \mathrm{~m}(\mathrm{r}-\mathrm{d})}{\mathrm{m} l_{0}-2 \mathrm{r}(\mathrm{r}-\mathrm{d})}
\end{aligned} \cdots \cdots
$$

となる。

このような試験では図20に見られるように $l$ 部 では曲げ，m部では引張りとなるので曲げ試験と 引張試験を組合せた試験方法であると思われる。 通常の引張試験においても, 引張試験片の中央部の くびれ伸びは大きいことは前に述べたが，乙の Ductility 試験のように中央部に荷重がかかる場 合には 1 部の伸びは $\mathrm{m}$ 部の伸びょりあ大きいと考 えられる。これは○リングと鋼球の径にあ関係する。

この Ductility Tester で測定した厚さ $0.035 \mathrm{~mm}$ の圧延したままの銅箔の伸びは $0.88 \%$,乙れを焼な ました場合の伸びは $9.5 \%$ であり,同一試料の引張 試験での伸びは，それぞれ $1.2 \%$ と $8.6 \%$ で両者 の測定值はよく一致している。

\begin{tabular}{|c|c|c|c|c|c|c|}
\hline \multirow{6}{*}{$\begin{array}{l}\text { 引 } \\
\text { 張 } \\
\text { 試 } \\
\text { 験 } \\
\text { 年 } \\
\text { 材 } \\
\text { 質 }\end{array}$} & \multicolumn{4}{|c|}{ JIS H 3100, G 3141} & \multirow{2}{*}{$\begin{array}{c}\text { 測 } \\
\text { 引張強さ } \\
\left(\mathrm{kg} / \mathrm{mm}^{2}\right)\end{array}$} & \multirow{2}{*}{$\begin{array}{c}\text { 値 } \\
\text { 伸 び } \\
\text { (\%) }\end{array}$} \\
\hline & 材 質 & JIS の記号 & $\begin{array}{l}\text { 引張強さ } \\
\left(\mathrm{kg} / \mathrm{mm}^{2}\right)\end{array}$ & $\begin{array}{c}\text { 伸 び } \\
\text { (\%) }\end{array}$ & & \\
\hline & 銅 & $\mathrm{C} 1100 \mathrm{P}-\mathrm{O}$ & 20 & 35 & 25 & 32 \\
\hline & 銅 & $\mathrm{C} 1100 \mathrm{P}-\mathrm{H}$ & 28 & 15 & 31 & 11 \\
\hline & 黄＼cjkstart銅 & $\mathrm{C} 2680 \mathrm{P}-\mathrm{O}$ & 28 & 40 & 32 & 40 \\
\hline & 鉄 & $\mathrm{SPCC}-\mathrm{S}$ & 28 & 34 & 31 & 35 \\
\hline \multicolumn{2}{|c|}{ 標準めっき条件 } & \multicolumn{5}{|c|}{$\begin{array}{l}\mathrm{pH}: 4.0 \text {, 浴温 : } 50^{\circ} \mathrm{C} \text {, 電流密度 : } 3 \mathrm{~A} / \mathrm{dm}^{2} \text {, 空気かきまぜ, } \\
\text { めっき厚さ: 両面で } 0.04 \mathrm{~mm}\end{array}$} \\
\hline
\end{tabular}

またワット浴から作製した 0.01 0.04mm の二 ッケルめっき䇴の伸びは Brenner らが発表してい

表 2 引張試験片の材質およびめっき条件 
る図16の伸び 1 ～4\%とよく一致し，めっきの伸 びはめっき厚さが厚くなるとともに大きくなる。 またニッケル一鉄合金めっきでも同様の結果を得 ている5)

一般に焼なましをしていない銅板および焼なま した銅板の伸びは，本実験の結果であ表 2 亿見ら れるように10数\%および30\%以上の伸びがあるの が普通であり，またワット浴からのニッケルめっ きの伸びは30\%以上というのが通常の引張試験で の結果である。

しかし，てれらの伸び\%は比較的厚い引張試験 片での測定值であって, 厚さが非常にうすく標点 間距離が比較的大きい引張試験片で測定した伸び \%は前に述べたような材料力学的因子から小さい。

Ductility Tester は曲げと引張を組合せた試 験法であるが， $l$ 部のくびれ伸びは大きいと考え られる。そして試験片の厚さがうすく標点間距離 が大きいので，伸び\%は通常の厚さの引張試験片 の引張試験での伸び\%に比べ小さな值となったと 考えられる。したがって, Ductility Tester に よるめっきの伸び\%は，うすいめっきでの引張試 験における伸び\%と同じ值となる。

\section{7. 結 論}

一般に材料力学的伸びは，均一伸びとくびれ伸 びに分類されているが，くびれ伸びは試験片の原 断面積と標点間距離によって大きく異なる。めっ
きの伸びあ，めっき厚さや試験方法などの材料力 学的条件によって大きく異なる。したがって，めっ きの伸びの測定においては，試験条件を明確にし， また，その評価に当っては試験法の材料力学的条 件を熟知しておかなければならない。

\section{参 考 文 献}

19）水本省三，縄舟秀美，川崎元雄；銅めっき層の機 械的性質，めっき皮膜の機械的性質们関する金属表面 技術協会研究分科会打よび電気鍍金研究会研究委員会 での口頭発表 $(1981-8)$

20) 平松実, 横山文雄, 西田典秀; $\mathrm{Ni}-\mathrm{Al}_{2} \mathrm{O}_{3}$ 複合め っき皮膜の機械的性質，めっき皮膜の機械的性質に関 する金属表面技術協会研究分科会抢よび電気鍍金研究 会研究委員会での口頭発表 $(1980-12)$

21) J.K. Dennis, T.E. Such; Nickel and Chromium Plating, p.147 (1972) Newnes Butterworths

22）たとえば日本材料学会編；金属材料強度試験法便覧 p。103（1977）養賢堂

23) C. Ogden, D. Tench, J. White; Rotaing Cylinder Method for Precis Tensile Testing of Electrodeposits, Plating and Surface Finishing, 67 [12] 50 (1980)

24) R. Heak, C. Ogden, D. Tench; Comparison of the Tensile Properties of Electrodeposits from Various Acid Cupper Sulfate Baths, Plating and Surface Finishing, 68, [10] 59 (1981)

25) S. Nakahara, Y. Okinaka, D.R. Turner; J. Testing and Evalution, 5, [3] 178 (1979)

26）林忠夫； A E S 第 2 回パルスめっきシンポジゥムに 参加して，電気鍍金研究会講演資料 $(1981-11)$

\section{電解式メッキ膜厚計}

\section{モデルG - 7}

一定面皘を一定電流で溶解した時、溶解した厚 さは時間に比例する事を利用した装置で、コク 一ル電解液と標準板及び特許エア一筧拌方式に より、電解効恝が低下せず常に高い精度を保つ ので、J I S 規格判定に使用され、各官庁、工業 試験所、研究所、各産業界で定評ある名测定器。 多層メッキの測定に最適で、各種金属被膜の他、 金メッキを0.006ミクロン迄高感度で測定する 機能を備えています。

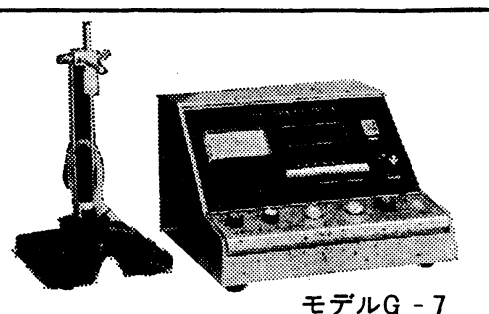

モデルG - 7

※お凬合せは直接当社にお䫝いします。

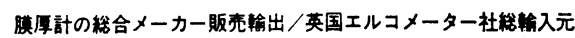
電 測 工業株 式会 社 ELEC FINE INSTRUMENTS CO.,LTD

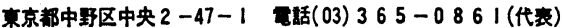
テレックス $232-3 \mid 31$ 